Beata Kurytowicz

Uniwersytet w Biatymstoku

\title{
Metaforyczne sposoby ujmowania \\ Boga i relacji Bóg - człowiek \\ w przysłowiach polskich
}

\section{METAPHORIC WAYS OF PRESENTING GOD AND THE RELATION BETWEEN GOD AND MAN IN POLISH PROVERBS}

The aim of the author is an attempt to show metaphoric ways of presenting God and the relations God-man in Polish proverbs. The analysis of the research material shows that figurative images of God are strictly related to everyday life and daily occupations of an average user of Polish, especially trade, craft, construction, medicine, finances, education. It is not odd that these branches of life, generally acknowledged and respected, have become a basis for depictions of God as the highest value. It is also vital that metaphorical images of God and His relations to man are identical with the Christian idea of the Creator. What is more, almost all the metaphors of God present in the research material have their equivalents in the quotations from the Scriptures. Thus, we observe both the influence of the Bible on common images of the nature of God and the impact of the original (dating back to the times when the Bible was coming into existence), 'naïve' and commmon-sense vision of the world on biblical images of the Creator.

Key words: proverbs, God, metaphor, imaging, language image of the world.

Przysłowia to zakorzenione w kulturze i tradycji społeczeństwa krótkie, o ustalonej strukturze teksty, w których zapisane są mądrość i doświadczenie narodu, przekazywane w sposób ciągły, z pokolenia na pokolenie. Wiedza, zawarta w prowerbiach, jest zdroworozsądkowa, 
Antropologia teologiczna

potoczna, akceptowana przez ogół ${ }^{1}$. Ten fakt nie może dziwić, ponieważ przysłowia wyrastają z mowy codziennej ludzi należących do wszystkich warstw i zawodów. Źródłem przysłów jest także „kościół, szkoła, myśli mędrców, filozofów i sławnych jednostek, myśli, które oderwały się od swych autorów i zaistniały jako anonimowa skarbnica wiedzy"2.

Trwałe miejsce w kulturze, powszechność, ogólna dostępność i zrozumiałość paremii upoważniają do stwierdzenia, że treści, których są one nośnikiem, mają skonwencjonalizowany czy wręcz stereotypowy charakter. Przysłowia odzwierciedlają sposób postrzegania i wartościowania świata właściwy danej społeczności. Odbijają się w nich przekonania, postawy, zasady moralne, system wartości, czyli to, co stanowi duchowe dziedzictwo narodu. Stąd też przysłowia jako wytwory kultury polskiej werbalizują wyobrażenia Boga, relacji Bóg - człowiek i człowiek - Bóg, typowe dla przeciętnego użytkownika polszczyzny.

W niniejszym szkicu naukowej refleksji zostaną poddane nie tylko tradycyjne przysłowia obrazowe, tzn. zawierające obraz słowny (trop) w postaci przenośni ${ }^{3}$, ale również te, których obrazowanie oparte jest na metaforze pojęciowej ${ }^{4}$. Metafora potoczna - zauważa R. Tokarski - dostarcza nam danych językowych, które stanowią podstawę do rekonstrukcji sposobów myślenia użytkowników języka o otaczającej rzeczywistości, o jej kategoryzowaniu i wartościowaniu ${ }^{5}$. Poprzez analizę potocznych metafor stanowiących konstrukcyjną oś przysłów możemy zatem odtworzyć obraz Boga ukryty w świadomości Polaków.

Mimo że Bóg jest pojęciem głęboko zakorzenionym w kulturze duchowej narodu polskiego, należy do sfery abstrakcji ${ }^{6}$, trudnej do wy-

1 T. Hołówka, Myślenie potoczne. Heterogeniczność zdrowego rozsądku, Warszawa 1986.

2 R. Wyżkiewicz-Maksimow, Językowy obraz człowieka - charakter i osobowość $w$ paremiologii polskiej, serbskiej i chorwackiej, Gdańsk 2012, s. 21.

$3 \quad$ Zob. J. Krzyżanowski, Mądrej gtowie dość dwie stowie. Pięć centuryj przysłów polskich $i$ diabelskich tuzin, t. 1, Warszawa 1975, s. 16.

4 Terminu metafora pojęciowa używam w znaczeniu, jakie nadali mu G. Lakoff i M. Johnson, autorzy książki Metafory w naszym życiu, przekł. T. P. Krzeszowski, Warszawa 1988.

$5 \quad$ R. Tokarski, Wartościowanie człowieka $w$ metaforach językowych, „Pamiętnik Literacki", 1/1991: s. 145.

6 Mowa tu o sferze abstrakcji w sensie lingwistycznym. Brak fizycznego, widzialnego desygnatu, do którego odsyła słowo Bóg (Boga nikt nigdy nie widział, możemy Go sobie tylko wyobrażać), podobnie jak w wypadku rzeczowników abstrakcyjnych nazywających uczucia (np. mitość, wierność), a w opozycji do nazw konkretnych, jak np. drzewo, które odsyła do materialnego obiektu z realnego świata. 
rażenia, a zatem poddanej metaforyzacji w szczególny sposób. W artykule zostanie podjęta próba wykazania, za pomocą jakich metafor jest modelowana i jak jest wartościowana wizja Stwórcy w przysłowiach Antropologia teologiczna oraz jakie dziedziny życia stały się podstawą obrazowego ujęcia relacji zachodzącej między Bogiem a człowiekiem.

Interesującą grupę przysłów stanowią te, w których stosunek człowieka do Boga przedstawiony jest za pomocą metafory handlu: „Dobry targ z Bogiem”, „Dobrze taki handluje, co Bogu nie żałuje”. W obu przysłowiach wyeksponowane jest pozytywne waloryzowanie sytuacji, w której człowiek wchodzi w relację handlową z Bogiem, wyrażone za pomocą przymiotnika dobry, a więc wyrazu prymarnie wartościującego ${ }^{8}$.

W obrębie pola semantycznego, wyznaczonego przez leksem handel, mieści się także paremia „Na zysk Bogu daje, który ubogim dobra swe rozdaje", w której składnik wartościujący należy do konotacyjnej strefy znaczenia leksemu zysk. Dodatnie nacechowanie wyraża się w niej poprzez przedstawienie zależności między człowiekiem a Bogiem w kategoriach zysku i straty. Wypełnianie Boskich przykazań, w tym wypadku jest to troska o ubogich wedle nauczania Chrystusa: „Wszystko, co uczyniliście jednemu z tych braci moich najmniejszych, Mnieście uczynili" (Mt 25, 40) ${ }^{9}$, jest tu ukazane jako pewna inwestycja, która w przyszłości przyniesie określony dochód - zysk.

Metaforyczna struktura omówionych przysłów odwołuje się do schematu poznawczego czy też sceny ${ }^{10}$ aktu „kupna - sprzedaży”11, która zawiera specyficzne relacje między rolami „sprzedającego”, „kupującego”, „obiektu sprzedawanego-kupowanego”, obecny jest

$7 \quad$ Przysłowia zostały wyekscerpowane z Nowej księgi przysłów i wyrażeń przysłowiowych polskich, t. 1, A-J, oprac. zesp. pod kier. J. Krzyżanowskiego, Warszawa 1969.

Por. J. Puzynina, Język wartości, Warszawa 1992, s. 120.

Cytaty biblijne pochodzą z: Pismo Święte Starego i Nowego Testamentu. Biblia Tysiąclecia, Poznań - Warszawa 1980.

Schemat poznawczy, scena (w literaturze językoznawczej funkcjonują różne terminy, których znaczenie jest zbliżone, obok wyżej wymienionych są to rama, skrypt, scenariusz, wyidealizowany model kognitywny) to sposób organizacji wiedzy w umyśle, innymi słowy można powiedzieć, że to mentalny czy też umysłowy obraz sytuacji, zdarzenia. Antropologowie podkreślają, że tego typu reprezentacja poznawcza ma charakter wspólnotowy, wywodzi się z typowych, powtarzalnych doświadczeń, będących udziałem członków danej grupy (W. Burszta, Antropologia kultury. Tematy, teorie, interpretacje, Poznań 1998).

11 Analizę aktu „kupna-sprzedaży” przeprowadził Ch. Fillmore, Topics in Lexical Semantics, [w]: R. W. Cole (red.), Current Issues in Linguistic Theory, Bloomington - London 1977. 
Antropologia teologiczna w niej także element „targu”, czyli “układania się o cenę tego, co jest przedmiotem handlu'. W przywołanych przysłowiach metaforyczne role „sprzedającego-kupującego” (nie są one podane wprost, ale dzięki przywołaniu schematu możemy je uaktywnić), obsadzone są przez Boga i człowieka, a istotę tej relacji stanowi szczodrość człowieka wobec Boga i wobec bliźnich. Życie zgodne z nauczaniem Chrystusa, metaforycznie wyrażone jako targ, handel z Bogiem, zaprocentuje nagrodą w życiu przyszłym, stąd też w paremiach mamy do czynienia z pochwałą hojności. Ten aspekt powoduje, że sytuacja przedstawiona w przysłowiach odbiega nieco od typowego zachowania dotyczącego handlowych targów, podczas których każda ze stron chce jak najwięcej zyskać i jak najmniej stracić.

Językowe obrazowanie relacji człowiek - Bóg za pomocą metafory targu nie jest odosobnionym przypadkiem w kulturze, znajduje on bowiem uzasadnienie w Biblii, która jest przecież podstawowym źródłem wiedzy o naturze Boga. Najbardziej znaną postacią biblijną, której rozmowa ze Stwórcą przybiera znamiona targu jest Abraham. Wstawia się on u Jahwe za niewinnymi mieszkańcami Sodomy i Gomory - miast, które mają zostać zniszczone. Abraham bliskowschodnim zwyczajem ludzi, którzy prowadzą interesy, spiera się, pertraktuje, targuje się z Bogiem, by ocalić ludzkie życie ( $\mathrm{Rdz} 18,23-33)$.

Wśród polskich przysłów obecne jest również takie, które przestrzega przed targowaniem się z Bogiem: „Nie trzeba się z Bogiem targować", kategoryzując jednocześnie takie zachowanie jako złe.

W polskiej paremiologii dość licznie poświadczone są prowerbia, w których Bóg ukazany jest w kategoriach gospodarskich. W części przysłów Stwórca wprost nazwany jest słowem gospodarz, któremu często towarzyszą przymiotniki stary, mądry, najlepszy lub najstarszy, z jednej strony podkreślające dostojeństwo, majestat i powagę Boga-Gospodarza, z drugiej natomiast wnoszące dodatnie wartościowanie: „Stary gospodarz Pan Bóg, wie, komu czego trzeba” i jego liczne warianty: „Mądry gospodarz Pan Bóg”, „Pan Bóg stary gospodarz”, „Stary gospodarz Pan Bóg”, „Najlepszy gospodarz pan Bóg”, „Pan Bóg najlepszy gospodarz” oraz „Stary gospodarz Pan Bóg, wie, kiedy komu czego trzeba”, „Stary gospodarz Bóg, wie, czego trzeba”, „Stary gospodarz Pan Bóg, wie, kiedy komu czego potrzeba”, „Stary gospodarz Pan Bóg, wie, czego komu potrzeba i czyj jaki dług”, „Pan Bóg najstarszy gospodarz wie, co robi”, „Stary gospodarz Pan Bóg, wie, jaki czyj dług”, „Dobry gospodarz Bóg z nieba, wie, czego komu potrzeba”.

Leksem gospodarz, który w dobie średniopolskiej znaczył 'właściciel gospodarstwa, posiadłości wiejskiej’ oraz 'pan domu, głowa rodziny, 
władca', wywodzi się z psł. *gospods 'gospodarz, pan, władca'. Słowo to dało początek także staropolskiej nazwie gospodzin, która w praktyce językowej odnoszona była tylko do Boga, np. w Bogurodzicy: „U Twego Syna Gospodzina...”12. Wydaje się zatem, że dwa wskazane wyżej znaczenia wyrazu gospodarz stały się podstawą mechanizmu przysłowiotwórczego opartego na przenośni ${ }^{13}$. Metafora gospodarza niejako łączy obraz Boga-Władcy i Boga-Właściciela gospodarstwa, którym jest świat - opiekuńczego, mądrego i znającego potrzeby swoich podopiecznych.

Przysłowie „Gdzie Bóg gospodarzy, tam się wszystko darzy”, w bezpośredni sposób eksponująca gospodarność Boga, wskazuje na pomyślność wynikającą z Bożej ingerencji w sprawy tego świata. Czasownik darzyć się znaczy wszakże 'szczęścić ś., udawać ś., wieść ś., iść po myśli' (SW) ${ }^{14}$. Z kolei w paremii „Bóg i liche kurczęta karmi” wykładnikiem metafory dobrego gospodarza jest grupa werbalna $i$ liche kurczęta karmi, która w obrazowy sposób ewokuje Boską opiekę nad całym stworzeniem, nawet tym najlichszym. Do wyobrażenia Boga jako dobrego gospodarza nawiązuje również przysłowie „Kiedy Pan Bóg rosi, ziemia plon przynosi, gdy człowiek poleje, to ledwie nadzieje", w którym gospodarskie atrybuty Stwórcy zostały uwypuklone przez skontrastowanie efektów Jego działań i pracy człowieka. Dodatkowym elementem akcentującym ten aspekt Bożej działalności jest użycie czasowników rosić w odniesieniu do Boga i polać do człowieka. Czasownik rosić, który oznacza 'kropić' ${ }^{15}$, wydobywa staranność, dbałość i pieczołowitość Boskiej aktywności, natomiast polać 'zlać, oblać co po wierzchu'16 implikuje bylejakość i brak zaangażowania.

Do świata jako wielkiego gospodarstwa nawiązuje przysłowie „Niech Pan Bóg radzi o swej czeladzi”, w którym słowo czeladź, oznaczające przecież 'służbę, domowników'17, jest obrazowym ekwiwalentem zbiorowości ludzkiej. Czasownik radzić (o kim) z kolei oznacza 'myśleć,

12 K. Długosz-Kurczabowa, Nowy stownik etymologiczny języka polskiego, Warszawa 2003, s. 161, W. Boryś, Stownik etymologiczny języka polskiego, Kraków 2005, s. 174

$13 \quad$ Por. J. Krzyżanowski, Madrej gtowie..., dz. cyt., s. 16.

14 J.Karłowicz, A. Kryński, W. Niedźwiedzki, Słownikjęzyka polskiego, Warszawa 1900-1927 (dalej: SW).

15 Tamże.

16 Tamże.

$17 \quad$ Tamże 
Antropologia teologiczna mieć pieczę, pamiętać, opiekować ś., troszczyć ś. ${ }^{18}$. I to przysłowie zatem akcentuje opiekuńcze przymioty Boga-Gospodarza.

Wśród przysłów, ukazujących Boga w kategoriach gospodarskich, występują paremie, które można uznać za swoiste uszczegółowienia, aktywizujące konkretne aspekty pracy w gospodarstwie, np.: „Boskie młyny pomału mielą, ale dobrze”, „Kiedy Pan Bóg rzeź bije, wtedy dziad gorzałkę pije" (mowa o stypach pogrzebowych).

Ostatnią grupę tej kategorii stanowią prowerbia, w których Bóg przedstawiony jest jako siła sprawcza, od której zależą plony, owoce ludzkiej pracy: „Człek sieje, a Bóg rodzi” i warianty: „Człek orze, sieje, zabiega, lecz plon na Bogu polega”, „Człowiek sieje, Bóg urodzaj daje”, „Chłop orze, Pan Bóg rodzi”.

Większość przysłów bazujących na metaforze gospodarza eksponuje konotacje Boga 'opieka', 'ochrona', 'troska o los człowieka'. Taki obraz Stwórcy jest mocno zakorzeniony w kulturze chrześcijańskiej, a wywodzi się z Biblii. W Księdze Mądrości czytamy: „Panie, nie ma oprócz Ciebie Boga, co ma pieczę nad wszystkim... (Mdr 13, 12). Chrystus mówił do swoich uczniów: „Przypatrzcie się krukom: nie sieją ani żną; nie mają piwnic ani spichlerza, a Bóg je żywi. O ileż ważniejsi jesteście wy niż ptaki!" (Łk 12, 24). W przypowieści Jezus porównał Królestwo Niebieskie do gospodarza, który z troski o pszenicę pozwolił rosnąć aż do żniwa zbożu i chwastom, zasianym przez nieprzyjaciela (Mt 13, 24-30).

Relację człowiek - Bóg przysłowia oddają także za pomocą obrazu służby. Takie obrazowanie wyraża podległość, podporządkowanie człowieka Bogu, a także ewokuje powodzenie, będące udziałem służących Bogu: „Kto Bogu służy, ma dobrego Pana, Kto Bogu służy, temu szczęście płuży”"19, „Najpewniejsza to wysługa, co z Boga idzie a z pługa". Stużba i stużenie mogą budzić negatywne skojarzenia (por. stużalczość, stużalstwo 'płaszczenie się przed kimś, uniżoność', służalczy 'uniżony, płaszczący się', stużalec 'osoba podporządkowująca się komuś, ślepo kogoś słuchająca, wykonująca wszystkie jego polecenia', stużbista 'ten, kto ściśle, zbyt pedantycznie wypełnia nakazy służbowe, przestrzega przepisów, regulaminu itp.'), w powyższych paremiach słowa te maja jednak nacechowanie dodatnie. Służba Bogu, zwłaszcza ta z serca, a nie z obowiązku („Nie z rejestru Bogu służyć trzeba”), ukazana jest jako wartość, przynosi człowiekowi wymierne korzyści, czyni szczęśliwym.

Tamże.

19 Ptu̇̇yć w odniesieniu do ludzi oznacza 'dobrze ś. mieć, być w dobrym stanie, opływać, bonować' (SW). 
W kategoriach służby przedstawia Boga paremia „Bogu służ, a diabła nie gniewaj”, której obrazowy wariant brzmi „Panu Bogu świeczkę, a diabłu ogarek". Pierwsza wersja - jak podaje S. Sarnicki - jest autorstwa Władysława Jagiełły, który był człowiekiem przesądnym i ostrożnym. Król, widząc w poznańskim kościele przesuwające się obrazy w ołtarzu, Chrystusowi kazał zapalić jedną świeczkę, diabłu zaś dwie, by go nie gniewać. Knapiusz z kolei pochodzenie przysłowia wiąże ze środowiskiem plebejuszy i wyjaśnia, że chrześcijanin nie powinien posługiwać się tym przysłowiem w sensie dosłownym ${ }^{20}$.

Innym sposobem wyrażenia stosunku podległości jest ujmowanie relacji między człowiekiem a Bogiem za pomocą metafor orientacyjnych góra - dół: „Wszyscy jesteśmy pod Bogiem”, „Widzi Pan Bóg z góry, jak tu żyje który”, „Widzi Pan Bóg z nieba, czego komu trzeba”.

Metaforyczne obrazowanie Boga i relacji Bóg - człowiek nawiązuje także do militarnej, wojennej aktywności ludzkiej, rzadko kojarzonej ze sprawami należącymi do sfery sacrum. Jednym z ciekawszych przysłów należących do tej klasy jest „Jak Pan Bóg dopuści, to i z kija wypuści” i jego najważniejsze warianty „Kiedy Bóg dopuści samo olstro spuści”, „Gdy Bóg dopuści, to i z kija strzał wypuści”. Geneza i znaczenie figuratywne tych paremii nie zostały jednoznacznie wyjaśnione, często są one interpretowane jako wyraz niezłomnej wiary w cudotwórczą moc Boga ${ }^{21}$. $\mathrm{Z}$ takim tłumaczeniem nie zgadza się J. Krzyżanowski, z którego ustaleń wynika, że starsza jest wersja zawierająca komponent olstro 'futerał na pistolety'22. Przysłowie w tej postaci zostało odnotowane w Wyprawie plebanskiej z 1590 roku, gdzie ma wymowę wyraźnie komiczną i cudu czy to w sensie religijnym, czy też folklorystycznym trudno się w nim doszukać. Młodsza wersja przysłowia, w której składnikiem jest kij, powstała prawdopodobnie w środowisku wojskowym. Zastąpienie olstra kijem Krzyżanowski tłumaczy nie tyle zapomnieniem starego wyrazu, ile „okolicznością, że już w wieku XVI i XVII kij bywał bronią wojskową, noszoną przez ciurów i chłopów do szeregów powołanych"23 .

Elementem składającym się na pojęcie wojny jest zwycięstwo. Słowo to tworzy centrum znaczeniowe przysłowia „Gdzie Pan Bóg, tam zwycięstwo”, w którym pobrzmiewa echo słów skierowanych do Gedeona

\footnotetext{
20 J. Krzyżanowski, Madrej gtowie..., dz. cyt., s. 99-100.

Zob. J. S. Bystroń, Przystowia polskie, Kraków 1932. s. 84, R. Wyżkiewicz-Maksimow, Językowy obraz człowieka..., dz. cyt., s. 111 gdy Bóg przypuści”. 
Antropologia teologiczna przez Anioła Pańskiego: „Pan jest z tobą, dzielny wojowniku!” (Sdz 6, 12) i późniejszego Pawłowego zawołania „Jeżeli Bóg z nami, któż przeciwko nam?" (Rz 8, 31). Paremia powyższa aktywizuje wyobrażenie Boga, który pomaga zwyciężać (nie tylko w sensie militarnym) tym, którzy Mu zawierzyli i zaufali. W Biblii opisanych jest wiele historii, które mówią o zwycięstwach Izraelitów, wspieranych mocą Boga, jak choćby wygrana bitwa z Amalekitami (Wj 17, 8-13) czy z Madianitami (Sdz 7, 8).

Przez odwołanie do pojęcia wojny kształtowany jest również obraz Boga w przysłowiu „Bóg jest zawsze przy najsilniejszych batalionach”. Jan Stanisław Bystroń twierdzi, że jest to powiedzenie Fryderyka Wielkiego, które stało się przysłowiem. Paremiolog tłumaczy także, że prowerbium to znaczeniowo bliskie jest innemu, a mianowicie „Strzeżonego Pan Bóg strzeże”, które uważa za „bezbożne przysłowie, stwierdzające, że pomoc Boska jest tylko czemś dodatkowem do samopomocy człowieka i że Bóg nie strzeże ludzi, nieumiejących o sobie pamiętać" 24 .

Prowerbium „Nadzieja w Bogu, nie w wojennym rogu” odradza natomiast podejmowanie działań wojennych, a zachęca do zawierzenia Stwórcy.

W strukturze pojęcia wojny mieści się także obrona, defensywa. $\mathrm{Na}$ bazie tego składnika, tworzącego model kognitywny wojny, zbudowana jest paremia „Nie schronią wieże, gdy Bóg nie strzeże”, odwołująca się do znanego z historii sposobu obrony przed wrogiem, polegającego na ukryciu się w wieży. Wyraz wieża oznaczał w przeszłości ‘baszta, dom z wieżą, sienią i izbą, jako bezpieczne schowanie' ${ }^{25}$.

Do obrony, aczkolwiek bardziej w sensie opieki, nawiązuje prowerbium „Kogo Bóg ma w swej obronie, ten w złej nawie nie utonie”26. Odwrotną sytuację, czyli brak ochrony Boskiej, przedstawia przysłowie „Kiedy Pan Bóg dopuści, to i nie obroni”, którego struktura także zasadza się na metaforze pojęciowej wojny.

W strategii wojennej istotne miejsce zajmuje odwód, czyli 'odsiecz, sukurs, pomoc wojskowa, ostatni ratunek ${ }^{27}$. Do tego elementu struktury pojęcia wojna odwołuje się metaforyczne obrazowanie w paremii „W najdotkliwszej przygodzie Pan Bóg stoi w odwodzie”, która także akcentuje Boską opiekę.

J. S. Bystroń, Przystowia polskie..., dz. cyt., s. 248.

SW.

Nawa to 'wszelki statek wodny' (SW).

SW. 
Przysłowie „Człowiek strzela, a Pan Bóg kule nosi” i jego warianty „Żołnierz strzela, a Pan Bóg kule nosi”, „Chłop nosi proch, a Pan Bóg kulki”, „Chłop strzela, a Pan Bóg kule nosi” w kategoriach wojny wyAntropologia teologiczna rażają przekonanie, że nie wszystko w życiu zależy od człowieka. Bóg został tu ukazany jako Ten, od którego zależą losy świata.

W niektórych przysłowiach słowo Bóg jest komponentem struktury realizującej metaforę pojęciową walki: „Z kim Bóg, ten bije”; „Kochaj Boga, a bij wroga".

Z kolei prowerbium „Trudno z Bogiem walczyć” wydaje się być refleksem biblijnej opowieści o walce Jakuba z Bogiem (Rdz 32, 25-33).

$\mathrm{W}$ polskiej paremiologii istnieją przysłowia, w których relacja między Bogiem a człowiekiem ukazana jest w kategoriach finansowych. Niektóre prowerbia wprost przypisują Bogu posiadanie pieniędzy, którymi może obdarować człowieka, np. „Do Boga - ma pieniądze” (tzn. dużo, mnóstwo), inne tę samą treść wyrażają w bardziej zawoalowany sposób. Przysłowie „Komu Bóg płaci, ten nigdy nie traci”, choć nie zawiera nazwy środka płatniczego, werbalizuje przekonanie, że Boże wsparcie w sferze finansów zapewnia zamożność. Z kolei w paremii „Bóg płaci, lecz nie co sobota”, nawiązującej do zwyczaju zapłaty za pracę w cyklu tygodniowym (tu w sobotę), tzw. potocznie tygodniów$k i$, uzewnętrznia się pogląd, że zawsze można spodziewać się zapłaty od Boga, choć niekoniecznie będzie ona miała charakter pieniężny. Podobne spojrzenie na kwestię Bożej zapłaty ujawniają przysłowia „Bóg płaci złym za złe, dobrym za dobre”, „Za dobre Bóg niebem płaci, a za złe piekłem karze”, które wskazują niebiańską szczęśliwość jako gratyfikację za dobre życie na ziemi.

Interesujące wyobrażenie Boga przedstawia prowerbium „Pan Bóg u hojnych panów podskarbim jest", które w bardzo obrazowy sposób ukazuje Boską pomoc w pomnażaniu majątku ludziom szczodrym, nie żałującym pieniędzy innym.

Przysłowie o biblijnej genezie „Bogu i mamonie służyć razem nie można" wyraźnie poucza, że zbytnie przywiązanie do wartości materialnych, do pieniędzy nie idzie w parze z życiem wedle prawa Bożego.

Podstawą metaforycznej interpretacji związku między Bogiem a człowiekiem może być również branża budowlana, za pomocą której paremie przeciwstawiają potęgę Boga słabości człowieka: „Co Bóg zbudował, tego ludzie nie zrujnują” i „Człowiek buduje, Bóg rujnuje”.

Nieco inaczej relację Bóg - człowiek ujmuje prowerbium „Kto w Bogu ufność pokłada, ten dobry fundament zakłada", w którym znalazło odbicie przekonanie, że ufność Bogu jest podstawą dobrego, solidnego życia. 
Antropologia teologiczna
Z budownictwem wiąże się także paremia „Bóg najlepszy rzemieślnik", przywodząca na myśl obraz Boga, który stworzył świat z niczego. Wydaje się, że taka konceptualizacja Boga bliska jest średniowiecznej wizji Boga-Architekta. W XIII wieku powstała miniatura, nieznanego autorstwa, Architekt wszechświata, przedstawiająca Boga, który przy pomocy wielkiego cyrkla tworzy kulę ziemską i gwiazdy. Bóg-Architekt, ubrany w purpurę, złoto i granat, a więc barwy królewskie, podkreślające godność i wyjątkowość osoby je noszącej, pochyla się nad stwarzanym światem, któremu nadaje kształt koła, symbolizującego Boską pełnię. W kolistości ziemi zawarta jest więc sugestia, że powołany do istnienia świat jest idealny. Wymowa tego przedstawienia współgra zatem z komponentem przysłowia najlepszy odnoszącym się do Boga-Rzemieślnika.

Z pewnością nieprzypadkowo mądrość ludowa skojarzyła Boga z rzemieślnikiem. Stownik warszawski w definicji wyrazu rzemieślnik 'człowiek trudniący ś. jakim rzemiosłem, rękodzielnik, profesjonalista' notuje dwa przykłady użycia słowa, rzucające światło na znaczenie i wpływ działalności rzemieślniczej na rozwój miast: „Dobry rzemieślnik z lada czego uczyni co dobrego” oraz „Rzemieślnikami miasta, a miastami państwa stoją". Dobry rzemieślnik był zatem cennym składnikiem życia gospodarczego i społecznego, stąd też pozytywne wartościowanie ludzi trudniących się rzemiosłem, wyrażone w omawianym przysłowiu.

Biblia pełna jest opisów uzdrawiającej mocy Boga, który powiedział do Mojżesza: „Jeśli wiernie będziesz słuchał głosu Pana, twego Boga, i będziesz wykonywał to, co jest słuszne w Jego oczach; jeśli będziesz dawał posłuch Jego przykazaniom i strzegł wszystkich Jego praw, to nie ukarzę cię żadną z tych plag, jakie zesłałem na Egipt, bo Ja, Pan, chcę być twym lekarzem" (Wj 5, 26). Apogeum tej sfery aktywności Boga widzimy w działalności Jezusa, który przemierzał całą Galileę „nauczając w tamtejszych synagogach, głosząc Ewangelię o królestwie i lecząc wszelkie choroby i wszelkie słabości wśród ludu" (Mt 4, 23). Obraz Boga-Lekarza, wywodzący się z Biblii, a potwierdzony z pewnością doświadczeniem zwykłych ludzi, którzy doznali cudownego uzdrowienia, leży u podstaw przysłów, które ujmują Boga i Jego Słowo w kategoriach medycznych: „Najlepszy lekarz Pan Bóg” i jego wariantu „Bóg lekarz najlepszy”, „Słowo Boże jest duszne lekarstwo”, „Doktor leczy, a Pan Bóg zdrowie daje”.

Przysłowia polskie ukazują Boga również przy wykorzystaniu metafory nauczyciela: „Miłość Boska najlepszy profesor”, „Ludzie uczą mówić, a Pan Bóg myśleć”. Wyobrażenie Boga-Nauczyciela ma swoje 
źródło i najpełniej realizuje się w osobie Chrystusa, który jest Słowem Boga - jak czytamy w Ewangelii Janowej. Jezus - Rabbi, a więc Mistrz, sam siebie nazwał Nauczycielem: „Otóż wy nie pozwalajcie nazywać Antropologia teologiczna się Rabbi, albowiem jeden jest wasz Nauczyciel (...). Nie chciejcie również, aby was nazywano mistrzami, bo jeden jest tylko wasz Mistrz, Chrystus" (Mt 23, 8.10).

Silnemu skonwencjonalizowaniu podlega wyobrażenie Boga jako władcy świata i sędziego. Jest ono tak mocno wpisane w strukturę naszego myślenia o świecie, że często zapominamy o metaforycznym pochodzeniu takiego obrazu. Przysłowia odbijają jak w zwierciadle to stereotypowe portretowanie Boga: „Bóg światem władnie” (rządzi) i warianty „Bóg stwórca i rządca świata”, „Bóg światem rządzi”, „Bóg wszystkim władnie, rządzi”, „Bóg wszystkim rządzi”, a także „Człek układa (zakłada), a Bóg włada”; „Bóg sądzi i Bóg rządzi”, „Dziwne sądy Boskie". Wizja Boga-Władcy i Boga-Sędziego swoimi korzeniami sięga oczywiście Biblii, gdzie wyraża się najpełniej: „Jeden jest Prawodawca i Sędzia, w którego mocy jest zbawić lub potępić” (Jk 4, 12), „Ojciec (...) cały sąd przekazał Synowi” (J 5, 22). „Przekazał Mu władzę wykonywania sądu, ponieważ jest Synem Człowieczym” (J 5, 27). „Bóg ustanowił Go sędzią żywych i umarłych” (Dz 10, 42). „Jeden jest Pan, jedna wiara, jeden chrzest. Jeden jest Bóg i Ojciec wszystkich, który [jest i działa] ponad wszystkimi, przez wszystkich i we wszystkich. (Ef 4, 5-6), ,jeden Pan, Jezus Chrystus, przez którego wszystko się stało i dzięki któremu my także jesteśmy" (1 Kor 8, 6$)$.

Przedstawione analizy przysłów, zawierających metaforyczne ujęcia Boga, upoważniają do sformułowania kilku konstatacji ogólniejszej natury. Przede wszystkim metaforyczne obrazy Boga i relacji między człowiekiem a Bogiem, wyłaniające się z paremii, są ściśle skorelowane z powszednim życiem, potocznymi wyobrażeniami i doświadczeniami zanurzonymi w codziennej rzeczywistości, z którą stykał się przeciętny użytkownik polszczyzny. Są to handel, gospodarstwo, rzemiosło, budownictwo, medycyna, finanse, edukacja, a więc dziedziny życia darzone powszechnym szacunkiem, stąd też nie dziwi, że stanowiły one podstawę do konkretyzowania wyobrażeń o Bogu jako wartości najwyższej. Na podkreślenie zasługuje również fakt, że przenośne sposoby portretowania Boga i Jego relacji z człowiekiem, obecne w przysłowiach polskich, są zbieżne z wizją Stwórcy właściwą religijnemu modelowi chrześcijaństwa. Zestawienie obrazów wyłaniających się z paremii z odpowiednimi cytatami z Biblii pokazuje, że niemal wszystkie metafory, za pomocą których wyrażony został w przysłowiach wizerunek Boga znajdują odzwierciedlenie w Świętej Księdze. Mamy 
Antropologia teologiczna zatem do czynienia z jednej strony z oddziaływaniem Biblii w zakresie sposobów obrazowania Boga na potoczne wyobrażenia Jego natury, z drugiej zaś - z wpływem pierwotnego (z okresu powstawania Pisma Świętego) zdroworozsądkowego oglądu fragmentu świata na biblijne przedstawienia Stwórcy.

Materiał paremiologiczny, poddany analizie, zawiera sądy i opinie na temat Boga i życia ludzkiego w aspekcie metafizycznym, właściwe pewnej grupie społecznej - Polakom, w zdecydowanej większości katolikom, których system wartości wywodzi się z tradycji chrześcijańskiej. Elementy rzeczywistości, łączone są ze sferą sacrum, i przede wszystkim osoba Boga, wokół której zogniskowany jest świat wartości katolickich, waloryzowane są pozytywnie. Najogólniej rzecz ujmując, Bóg jawi się w przysłowiach jako Wszechmocny, a zarazem troskliwy opiekun, zapewniający ochronę tym, którzy się do niego uciekają. Jego karząca ręka dosięga jednak ludzi postępujących wbrew prawu Boskiemu. Takie modelowanie semantyki słowa Bóg potwierdza tezę, że w polskiej kulturze ludowej i kulturze codziennej, której emanacją jest język potoczny, symbolika katolicka wartościowana jest dodatnio ${ }^{28}$.

$\mathrm{Na}$ koniec jeszcze jedna uwaga, a mianowicie mimo różnic kulturowych, światopoglądowych, geograficznych, historycznych i przede wszystkim czasowych dzielących Izraelitów i Polaków pewne dziedziny życia i związane z nimi doświadczenia, a także sądy i opinie są zbieżne, a zatem można tu postawić tezę o uniwersalnym, wspólnym całemu gatunkowi ludzkiemu doznawaniu świata, przynajmniej w niektórych jego przejawach. Dotyczy to zwłaszcza spraw najważniejszych, do których z pewnością zaliczyć można sferę życia skoncentrowaną wokół pojęcia Boga. Przysłowia realizują zatem pewne schematy mówienia zintegrowane z całością kultury ludzkiej.

Słowa kluczowe: przysłowia, Bóg, metafora, obrazowanie, językowy obraz świata.

$28 \quad$ R. Tokarski, Językowy obraz świata w metaforach potocznych, [w:] J. Bartmiński (red.), Językowy obraz świata, Lublin 1999, s. 65-81 